\title{
PKLR Gene Mutation
}

National Cancer Institute

\section{Source}

National Cancer Institute. PKLR Gene Mutation. NCI Thesaurus. Code C157141.

A change in the nucleotide sequence of the PKLR gene. 